\title{
Sektor Luar Negeri \\ Indonesia Abad Ke 21 : Globalisasi dan \\ Hubungan Ekono-Politik
}

\author{
Endang Sih Prapti
}

Pendahuluan

ahun 2020 Indonesia akan

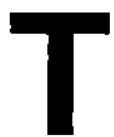

memasuki era globalisasi.

Tatanan hubungan ekono-politik global umumnya, keterkaitan ekono-politik antara Indonesia dengan dunia khususnya, akan banyak berpengaruh kepada kesiapan Indonesia menghadapi tantangan era globalisasi tersebut.

Sektor luar negeri Indonesia telah mengalami pasang surut selama kurun waktu 51 tahun. Banyak keberhasilan yang dicapai, meskipun masih banyak pula kelemahan-kelemahan yang belum berhasil diatasi, yang cenderung menjadi persisten. Pengaruh hubungan ekonopolitik global dianggap menjadi sumber penyebab utama kelemahan-kelemahan persisten sektor luar negeri Indonesia, terutama karena menjadikan Indonesia menjadi dependen hampir dalam semua aspek ekonomi internasionalnya, meliputi ketergantungan pasar, ketergantungan investasi atau modal, ketergantungan bantuan, ketergantungan teknologi, dan bahkan ketergantungan sebagai negara bekas jajahan. Oleh karenanya, dalam menghadapi era globalisasi sangatlah diperlukan adanya pergeseran hubungan ekono-politik antara indonesia dengan dunia menuju kepada interdependensi atau hubungan mitra sederajat, atau paling tidak dapat diawali dengan dependensi dua arah.

Kelemahan-kelemahan Persisten Sektor Luar Negerl Indonesia

Kelemahan sektor luar negeri Indonesia hampir ada di setiap aspek:

1). Keterbukaan ekonomi Indonesia.

Dari Tabel 1 dapat dilihat bahwa dari dekade 1960-an ke dekade 1980-an angka keterbukaan perekonomian Indonesia mengalami peningkatan, baik dari sisi ekspor (dari rata-rata sebesar 11 menjadi 33) maupun dari sisi impor (dari ratarata sebesar 9 menjadi 16). Pada dekade 1990-an angka keterbukaan dari sisi impor tetap meningkat menjadi sebesar 20 , sedangkan dari sisi ekspor menurun menjadi 26.

Tabel 1. Derajat Keterbukaan Perekonomian Indonesia

\begin{tabular}{|c|c|c|c|c|c|}
\hline \multirow[t]{2}{*}{ Dekade } & \multicolumn{2}{|c|}{$\begin{array}{l}\text { Angka Keterbukaan } \\
\text { rata-rata }\end{array}$} & \multirow[t]{2}{*}{ Dekade } & \multicolumn{2}{|c|}{$\begin{array}{l}\text { Angka Keterbukaan } \\
\text { rata-rata }\end{array}$} \\
\hline & X/GDP & M/GDP & & X/GDP & $M / G D P$ \\
\hline $\begin{array}{l}1960 \text {-an } \\
1970 \text {-an }\end{array}$ & $\begin{array}{l}11 \\
31\end{array}$ & $\begin{array}{r}9 \\
15\end{array}$ & $\begin{array}{l}\text { 1980-an } \\
1990 \text {-an }\end{array}$ & $\begin{array}{l}33 \\
26\end{array}$ & $\begin{array}{l}16 \\
20\end{array}$ \\
\hline
\end{tabular}

Sumber data : Diolah dari data ekspor, impor dan GDP dari International Financial Statistics, IMF, berbagai terbitan 
Melihat besarnya angka keterbukaan ekspor, dapat dilihat bahwa ketergaritungan perekonomian Indonesia pada ekspor sangat besar, karena lebih dari $25 \%$ pendapatan nasional Indonesia bergantung ekspor. Di lain pihak, angka keterbukaan impor menunjukkan bahwa porsi pendapatan nasional yang dibelanjakan untuk impor juga cukup besar, mencapai seperlima dari pendapatan nasional dalam dekade terakhir.

Di samping itu, dampak dari perekonomian Indonesia yang cukup terbuka ini adalah mudah masuknya pengaruh perekonomian luar negeri kepada Indonesia. Sebagai contoh : (1) pada waktu negara-negara maju mengalami resesi akibat embargo minyak oleh OPEC atas usul Irak, dampaknya adalah defisit neraca perdagangan Indonesia meningkat tajam (1980 dan 1981), karena kebijakan negara-negara maju mengurangi impor dan meningkatkan ekspor untuk mengatasi defisit tersebut, (2) pada waktu Yen apresiasi terhadap Dolar AS yang menyebabkan memperbesar defisit Indonesia, (3) pada waktu Amerika Serikat menaikkan suku bunga untuk menanggulangi Yendaka, Indonesia harus turut menaikkan suku bunga dengan kenaikan yang lebih besar (sekitar 4 kali kenaikan suku bunga AS) untuk mencegah capital flight.
2). Perimbangan Imbalan Faktor Produksi Antar Negara

Dalam hubungan pengerjaan faktor produksi antar Indonesia dengan negara-negara lain, Tabel 2 menunjukkan angka imbalan bersih (Net Factor Income From Abroad) atau $R$ yang selalu negatif. Keadaan ini menunjukkan bahwa pembayaran atas pengerjaan faktor produksi asing di Indonesia selalu jauh lebih besar dibanding pembayaran yang dilakukan oleh negara mereka. Selisihnya menunjukkan angka $R$ negatif yang sangat besar dan semakin membesar, mencapai hampir 11 triliun Rupiah di tahun 1991. Hal ini sangat memprihatinkan, karena uang sebesar itu seharusnya lebih tepat jika digunakan untuk pembayaran kepada faktor produksi Indonesia di negaranya sendiri. Dua faktor utama menjadi penyebab negatifnya $R$ indonesia, (1) posisi Indonesia yang sebagai negara debitur baik dalam hutang maupun dalam modal, (2) banyaknya lembaga-lembaga Indonesia, baik swasta maupun Pemerintah, jika berkesempatan memilih, masih lebih suka menggunakan tenaga-tenaga asing dibanding tenaga Indonesia.

Tabel 2. Imbalan Bersih Faktor Produksi Antar Negara atau R antara Indonesia dengan Luar Negeri, 1968-1991 (dalam milyar Rupiah)

\begin{tabular}{|lr|lr|l|l|l|}
\hline Tahun & R & Tahun & R & Tahun & R & Tahun \\
\hline $1968-$ & 29 & $1974-507$ & $1980-2011$ & $1986-4193$ \\
$1969-$ & 35 & $1975-556$ & $1981-1930$ & $1987-6022$ \\
$1970-$ & 50 & $1976-432$ & $1982-1980$ & $1988-6922$ \\
$1971=$ & 67 & $1977-679$ & $1983-3283$ & $1989-8074$ \\
$1972-$ & 159 & $1978-892$ & $1984-4183$ & $1990-9619$ \\
$1973-$ & 246 & $1979-1484$ & $1985-3841$ & $1991-10760$ \\
\hline
\end{tabular}

Sumber data : Intemational Financial Statistics, IMF berbagai terbitan (Catatan : R = GNP - GDP) 
3). Defisit Neraca Jasa dan Defisit Neraca Non Migas

Tabel 3 juga jelas sekali menunjukkan aspek kelemahan persisten sektor luar negeri Indonesia yang lain, yaitu pada neraca perdagangannya. Jika dilihat dari neraca perdagangan barang saja, kelemahan ini tidak terlihat, karena Indonesia selalu mengalami surplus yang didukung oleh surplus neraca migas, karena Indonesia adalah negara produsen-eksportir migas. Tetapi surplus neraca barang ini menunjukkan perkembangan yang mengkhawatirkan karena bila dilihat neraca non-migasnya, Indonesia selalu mengalami defisit sedangkan surplus migasnya mengalami penurunan.

Kelemahan lainnya ditunjukkan oleh neraca jasa yang senantiasa defisit dengan jumlah yang semakin meningkat. Dari dekade 1960-an sampai dekade 1990-an terlihat bahwa surplus migas semakin berat bebannya untuk mengatasi defisit non migas dan defisit jasa, sehingga neraca perdagangan Indonesia hampir selalu diwarnai dengan defisit.

Bebarapa faktor utama penyebab persistennya defisit neraca non migas, adalah : (1) ketergantungan pada ekspor barang primer dan sekunder, (2) lemahnya daya saing pada barang-barang tersier karena masih bertumpu kepada efek pertumbuhan (pasar) dunia, (3) ketidakmampuan mengatasi restriksi yang dipaksakan oleh negara-negara pengimpor karena lemahnya bargaining power Indonesia, sehingga seringkali ekspor Indonesia hanya merupakan pemenuhan kuota saja, dan impor Indonesia seringkali merupakan pemaksaan resiprokal, (4) banyak industri ekspor yang merupakan relokasi dari perusahaanperusahaan asing dimana indonesia, sehingga teknologi yang digunakan seringkali merupakan teknologi baru bagi Indonesia, dan devisa ekspor industri relokasi tersebut tidak sepenuhnya milik Indonesia, dan (5) ketergantungan terhadap barang impor, baik barang konsumsi maupun bahan baku dan barang antara produksi yang semakin berat.

Sedangkan penyebab persistennya defisit neraca jasa, adalah karena Indonesia selalu defisit hampir di semua sub neracanya, meliputi : (1) neraca angkutan, (2) neraca pendapatan modal dan bunga, (3) neraca jasa Pemerintah, dan (4) neraca jasa swasta.

Defisit neraca (1) sulit diatasi, karena ketinggalan terlalu jauh dalam teknologi dan pengalaman transportasi, sedangkan defisit neraca 92) adalah akibat besarnya hutang luar negeri dan penanaman modal asing yang masuk ke Indonesia. Pengatasan defisit neraca (3) dan (4) di samping memerlukan pembangunan sumberdaya manusia Indonesia agar dapat bersaing dengan tenaga kerja asing, juga memerlukan good will Pemerintah dan swasta untuk mengutamakan pengerjaan tenagakerja Indonesia. Sumbangan devisa jasa utama Indonesia baru dari jasa pariwisata, dan dari jasa pengiriman TKI dan TKW ke luar negeri.

4). Hutang Luar Negeri Indonesia dan Modal Asing.

Satu lagi kelemahan persisten Indonesia adalah dalam hal Hutang Luar Negeri dan Modal Asing. Dalam kedua aspek sektor luar negeri ini Indonesia dikenal sebagai negara netto debitur. Hutang luar negeri 
Indonesia sudah mencapai di atas 100 milyar dollar AS, yang menempatkan indonesia sebagai negara penghutang ketiga terbesar di dunia, setelah Meksiko dan Brazil. Sedangkan besarnya PMA yang masuk ke Indonesia memang merupakan hasil UU PMA 1966 yang dibarengi dengan sistem devisa bebas yang diadopsi oleh Indonesia. Meskipun pembangunan memerlukan mobilisasi dana baik dari dalam negeri maupun dari luar negeri, namun demikian perlu dilakukan secara efisien dan hatihati baik dari ukuran jumlahnya maupun laju pertumbuhan hutang dan PMA itu sendiri. Di samping itu perlu juga dipikirkan siapa penerima manfaat dan siapa penanggung beban pengembaliannya.

Tabel 3. Neraca Perdagangan Indonesia (Netto), 1969-1992

(Surplus : +; Defisit : -)

\begin{tabular}{|c|c|c|c|c|c|}
\hline Tahun & $\begin{array}{r}\text { Total } \\
\text { Barang }\end{array}$ & $\begin{array}{l}\text { Total } \\
\text { Jasa }\end{array}$ & $\begin{array}{r}\text { Total Barang } \\
\text { dan Jasa }\end{array}$ & Migas & Non Migas \\
\hline 1969 & 730 & -448 & 282 & 372 & -299 \\
\hline $\begin{array}{l}1970 \\
1971 \\
1972 \\
1973 \\
1974 \\
1975 \\
1976 \\
1977 \\
1978 \\
1979\end{array}$ & $\begin{array}{r}107 \\
131 \\
216 \\
482 \\
3584 \\
2333 \\
2873 \\
4622 \\
4953 \\
8388\end{array}$ & $\begin{array}{r}-490 \\
-574 \\
-845 \\
-1295 \\
-2227 \\
-2591 \\
-2842 \\
-3684 \\
-4065 \\
-5591\end{array}$ & $\begin{array}{r}-383 \\
-443 \\
-629 \\
-813 \\
1357 \\
-258 \\
31 \\
938 \\
888 \\
297\end{array}$ & $\begin{array}{l}432 \\
458 \\
883 \\
1565 \\
5108 \\
5057 \\
5566 \\
6646 \\
7405 \\
9370\end{array}$ & $\begin{array}{l}-325 \\
-327 \\
-667 \\
-1083 \\
-1444 \\
-2725 \\
-2693 \\
-2023 \\
-2453 \\
-982\end{array}$ \\
\hline $\begin{array}{l}1980 \\
1981 \\
1982 \\
1983 \\
1984 \\
1985 \\
1986 \\
1987 \\
1988 \\
1989 \\
\end{array}$ & $\begin{array}{l}1312 \\
1189 \\
5469 \\
4794 \\
8006 \\
8328 \\
4087 \\
4765 \\
5790 \\
5799\end{array}$ & $\begin{array}{l}-6512 \\
-7873 \\
-7215 \\
-7663 \\
-7442 \\
-7892 \\
-6297 \\
-7098 \\
-7372 \\
-8055\end{array}$ & $\begin{array}{r}-5200 \\
-6684 \\
-1746 \\
-2869 \\
564 \\
436 \\
-2031 \\
-2333 \\
-1582 \\
-2256\end{array}$ & $\begin{array}{l}16033 \\
18942 \\
14854 \\
11996 \\
13321 \\
11446 \\
7190 \\
7488 \\
6773 \\
7484\end{array}$ & $\begin{array}{r}-2914 \\
-7042 \\
-9385 \\
-2202 \\
-5316 \\
-3119 \\
-3104 \\
-2723 \\
-8025 \\
-1684\end{array}$ \\
\hline $\begin{array}{l}1990 \\
1991 \\
1992\end{array}$ & $\begin{array}{l}3838 \\
3274 \\
6285\end{array}$ & $\begin{array}{r}-8856 \\
-9263 \\
-9900\end{array}$ & $\begin{array}{r}-5018 \\
-5989 \\
-3615\end{array}$ & $\begin{array}{l}9151 \\
8761 \\
9288\end{array}$ & $\begin{array}{r}-5312 \\
-5487 \\
-3003\end{array}$ \\
\hline
\end{tabular}

Sumber data : Statistik Indonesia BPS, 1992 Nota Keuangan dan RAPBN 1993/1994 Dep. Keuangan 
Di antara negara-negara kreditor. yang serius membantu Indonesia adalah Jepang dan Belanda, baik melalui IGGI maupun CGI, dimana kedua negara tersebut adalah bekas penjajah Indonesia (lihat Tabel 4).

Dari penjelasán di atas, terlihat kelemahan-kelemahan persisten sektor luar negeri Indonesia, hampir di semua aspek sektor luar negeri. Kelemahan persisten ini menimbulkan ketergantungan Indonesia hampir di segala bidang : (1) ketergantungan pasar, (2) ketergantungan hutang. (3) ketergantungan modal, (4) ketergantungan bantuan, (5) ketergantungan teknologi, (6) ketergantungan moneter, dan (7) ketergantungan kepada bekas penjajah.

Di samping pengaruh faktor-faktor penyebab yang lain, kelemahan persisten ini sangat dipengaruhi oleh konstalasi tatanan hubungan ekono-politik global yang berdampak kepada hubungan ekonopolitik Indonesia dengan negara-negara lain.

\section{Sejarah Keterkaitan Antara Ekonomi dan Politik.*}

Pembahasan keterkaitan politik dan ekonomi dalam studi hubungan internasional dikenal sejak jaman Merkantilisme (abad 15-18). Kesatuan ekono-politik tersebut selanjutnya "dipisahkan" di akhir abad ke 18, antara lain karena : (1) terjadinya kemapanan, atau terlalu menyita perhatiannya tiap bidang, sehingga tidak diperiukan keterkaitan dengan bidang yang lain; (2) munculnya spesialisasi yang dianut oieh dunia akademi moderen; (3) ajaran dunia akademi Barat moderen, liberalisme, dengan alasan sistem politik yang terdiri dari kekuasaan, pengaruh, pembuatan keputusan dan aturan, serta tidak patuh pada harmoni alami, tidak selayaknya mencampuri aturan ekonomi yang harmoni dan alami, dalam mencapai perdamaian dan harmoni dalam perekonomian, dimana perdagangan bebas antar negara akan membawa bukan hanya kemakmuran untuk semua, tetapi juga perdamaian pada semua.

Dalam era pasca PD II terdapat tiga perkembangan yang membuat pemisahan antara ekonomi dan politik menjadi mantap, yaitu (1) adanya hubungan ekonomi yang mapan dan terpisah antara sistem Barat dengan sistem Bretton Woodsnya, dan sistem Timur dengan hegemoni Rusia atas Eropa Timur yang menetapkan aturan dasar sistem ekonomi secara mandiri dan terpisah; (2) sebagian besar negara Dunia Ketiga menjadi subordinasi dan bergantung pada hubungan imperial secara politik maupun ekonomi dengan negara-negara Barat. Mereka hanya memiliki satu pilihan, yaitu menyesuaikan diri dalam sistem ekonomi internasional yang telah ditentukan bagi mereka; dan (3) timbulnya Perang Dingin membuat problema utama hubungan internasional terfokuskan pada isu keamanan menghadapi penganuh Uni Soviet dan blok Eropa Timurnya.

Dalam perkembangan selanjutnya, awal tahun 1970-an, hubungan internasional terlihat mulai menyatu kembali studi ekonomi dan studi politik, karena 3 alasan : (1) isu politik dan keamanan semakin mereda dan tidak menyita perhatian, (2) runtuhnya sistem Bretton Woods, dan (3) munculnya kekuatan politik dan ekonomi baru dari Dunia Ketiga.

Ekonomi dan politik sekarang dirasakan perlu untuk dijembatani kembali, perlu digali keterkaitan antara ekonomi dan politik dalam sistem internasional, terutama tentang satu aspek dari keterkaitan

") Tulisan ini merupakan cuplikan dari makalah yang disampaikan penulis dalam Seminar Internasional Strategi Pembangunan Ekonomi dan Bisnis Di Indonesia : Refleksi dan Aktualisasi, dalam rangka Dies Natalis FE-UGM ke 40 tahun 1995 berjudul : "Lingkungan Ekono-Politik Global Perdagangan Luar Negeri Indonesia". 


\section{Tabel 4 \\ Reallsasl Bantuan Luar Negerl 1987 - 1992 \\ (Dalam Juta US\$)}

Negara-negara CGI

$\begin{array}{llllll}1987 & 1988 & 1989 & 1990 & 1991 & 1992\end{array}$

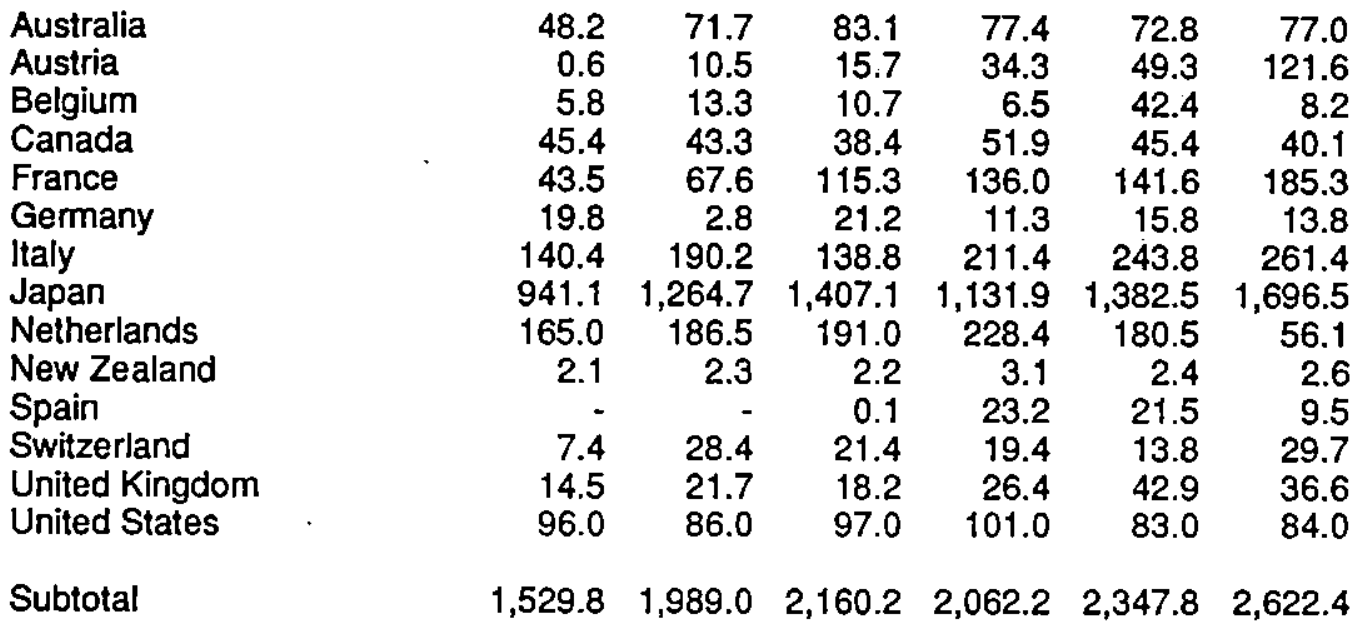

Negara-negara non CGI

Denmark

Findland

Ireland

Nonway

Sewden

Negara-negara Arab

Subtotal

Total

(*)
0.8

1.8

0.6

0.8

1.1

11.5

5.8

5.7

2.7

3.0

5.9

3.3

2.2

1.2

0.3

3.1

1.8

0.0

$0.8 \quad 12.6$

$\begin{array}{llllll}24.4 & 27.9 & 20.5 & 39.2 & 23.1 & 22.5\end{array}$

$\begin{array}{llllll}28.4 & 34.5 & 39.0 & 48.0 & 30.2 & 43.2\end{array}$

$\begin{array}{llllll}1,558.2 & 2,023.5 & 2,199.2 & 2,110.2 & 2,378.0 & 2,665.6\end{array}$

62

61

64

65

64
55

59

58
65

64

Sumber : IBRD Debtor Reporting System, berdasarkan data yang disediakan oleh Bank Indonesia sebagaimana yang dikutip dari Indonesia, Dimensions of Growth, Laporan Bank Dunia, 7 Mei 1996

(*) Pangsa Jepang dalam Total Bantuan CGI

(**) Pangsa Jepang dalam Total Bantuan 
tersebut, yaitu cara bagaimana politik internasional membentuk ekonomi. internasional.

\section{Dinamika Pengaruh Politik terhadap Ekonoml}

Selama ini, interaksi antara ekonomi dan politik hampir selalu diartikan bagaimana caranya ekonomi membentuk politik. Hal yang sebaliknya, yaitu bagaimana caranya faktor politik membentuk hasil ekonomi, sering dilupakan. Ada tiga cara faktor politik membentuk hasil ekonomi : (1) sistem politik membentuk sistem ekonomi, dimana struktur dan operasi dari ekonomi internasional ditentukan oleh struktur dan operasi dari sistem politik internasional, yang artinya konsumsi, produksi, dan distribusi dibentuk oleh faktor-faktor diplomasi dan strategi; (2) kepentingan politik sering membentuk kebijakan ekonomi, dimana kebijakan ekonomi sering didikte oleh supermasi kepentingan politik; (3) hubungan ekonomi internasional adalah hubungan politik, yang artinya interaksi ekonomi internasional adalah suatu proses dimana para pelaku mengatur (atau gagal mengatur) konflik-konflik mereka dan selanjutnya bekerjasama (atau gagal bekerjasama) untuk mencapai tujuannya.

Munculnya sistem imperialisme yang dilatarbelakangi oleh adanya hubungan antar negara berkekuatan setara dan dilandasi semangat nasionalisme, menyebabkan dalam beberapa dekade, sebagian besar Asia dan hampir seluruh Afrika telah dibagi-bagi antara Eropa Barat dan Amerika Serikat. Imperialisme ini menjadi dasar dari sistem ekonomi internasional baru, dimana dominasi politik mengarah kepada dominasi dan eksploitasi ekonomi. Negara-negara jajahan diintegrasikan pada sistem ekonomi internasional yang telah dirancang untuk melayani kepentingan dari pusat kekuasaan (penjajah). Para pemenang politik mengontrol investasi dan perdagangan, meregulasi matauang dan produksi, dan memanipulasi tenaga Kerja, jadi menetapkan struktur ekonomi ketergantungan pada koloni-koloni mereka, dimana ketergantungan ini berlangsung lebih lama dari otoritas politik mereka yang sebenarnya. Sistem imperialisme ini akhimya runtuh di bawah tekanan PD II:

Pada periode pasca PD II, sistem politik juga telah membentuk sistem ekonomi. Sistem politik dan ekonomi terisolasi menjadi dua sistem yang berbeda, berlandaskan pada konfrontasi tajam bipolar antara Barat di bawah kepemimpinan AS, dan Timur di bawah kepemimpinan Uni Sovyet. Di antara kedua kutub tersebut terletak posisi Dunia Ketiga, yang pada umumnya secara politik masih tetap menjadi subordinasi dari sistem imperialisme yang lama. Fisi liberal AS telah membentuk aturan ekonomi di Barat, dengan perdagangan bebas dan aliran modal bebas. Dengan sistem tersebut, investasi dan dollar AS mendominasi dunia. Pada gilirannya, penurunan kekuatan AS dan peningkatan pluralisme di Barat, peredaan ketegangan para adikuasa, dan konsensus politik baru di LDCs, kembali mengubah sistem ekonomi internasional.

\section{Kepentingan Politik dan Kebljakan Ekonomi}

Di samping berperan dalam pembentukan sistem ekonomi, faktor-faktor politik juga mempengaruhi penyusunan kebijakan ekonomi. Kebijakan ekonomi adalah hasil dari proses tawar-menawar politik, dimana kelompok-kelompok yang berbeda mewakili minat dan konflik pada pilihan hasil kebijakan yang berbeda. Kebijakan yang dihasilkan dari konflik politik ditentukan oleh kekuasaan. Dalam ruang lingkup internasional, proses tawarmenawar politik sering dipengaruhi oleh kepentingan strategi dan diplomatik yang berlebihan. Kebijakan ekonomi yang dibentuk oleh kepentingan politik akan menjadi alat kebijakan strategi dan 
diplomatik, serta dikaitkan pada tujuan politik atau pertahanan militer. Embargo, misalnya, telah menjadi alat ekonomi dari perang politik sepanjang sejarah; kebijakan proteksionisme telah digunakan untuk menghindariketergantungan pada sumber pemasokan asing yang sewaktu-waktu dapat diputuskan bila terjadi konflik politik atau perang; bantuan asing adalah alat ekonomi lain yang sering digunakan untuk tujuan strategi dan diplomatik.

\section{Sistem Hubungan Ekono-Polltik Global}

Sistem hubungan ekono-politik global dapat dibedakan menjadi empat macam, yaitu interdependensi, independensi, dan dependensi.

1) Interdependensi

Sistem interdependensi dianut oleh sistem Barat, yaitu dalam hubungan antar negara-negara maju, yaitu Amerika Utara, Eropa Barat, dan Jepang (menyusul tahun 1960-an), yang sederajat. Negara-negara ini sama-sama kaya, memiliki tingkat pembangunan yang tinggi, dan kapitalis. Mereka mempunyai keterkaitan ekonomi internasional yang kuat satu sama lain, dan terlibat dalam sistem yang padat akan interaksi ekonomi, yang di satu pihak saling -menguntungkan, tetapi di lain pihak seringkali menjadi masalah pokok dalam manajemen Sistem Barat, terutama dalam keadaan resesi ekonomi.

Pertanyaan yang sering timbul adalah "adakah alat manajemen yang memadai untuk mengatur hubungan ekonomi internasional dalam situasi interdependensi ?'. Dari sudut pandang negara secara individual, adanya interdependensi telah mencampuri kebijakan nasional dan kemampuan suatu negara untuk mengontrol ekonominya. Semakin besar derajat interdependensi, semakin besar pula jumlah gangguan eksternal yang harus diatasi oleh para pembuat keputusan nasional. Dalam usaha mencari penyelesaian secara penuh dan efektif bagi krisis domestik, para pengambil keputusan terpaksa semakin mementingkan solusi nasional dan mengurangi kontak-kontak internasional. Pada saat yang sama, manajemen internasional tidak mencukupi. Liberalisme tidak Iagi merupakan dasar manajemen yang memadai. Liberalisme yang mengurangi hambatan aliran perdagangan dan modal, memungkinkan terjadinya ekspansi cepat dalam interaksi ekonomi internasional antar mereka, dan malah menciptakan interdependensi itu sendiri. Struktur dan kepemimpinan yang ada tidak mampu mengontrol interdependensi.

Tampaknya sistem ekonomi internasional Barat tiba pada posisi di persimpangan jalan. Negara-negara maju telah mencapai satu titik dimana mereka menghadapi pilihan mendasar, apakah melanjutkan langkah hingga mencapai manajemen masalah secara kolektif, ataukah menghentikan interdependensi, dan membawa masalah ke dalam ruang lingkup pengawasan nasional.

Interdependensi juga menimbulkan dua macam reaksi dan tantangan yang berbeda terhadap liberalisme. Reaksi pertama menginginkan dilakukannya proteksionisme untuk membatasi interaksi ekonomi dan meningkatnya interdependensi. Reaksi kedua menginginkan menjangkau lebih jauh dari liberalisme, yaitu suatu bentuk manajemen kerjasama ekonomi internasional baru yang dapat mengatur interdependensi. Manajemen baru inilah yang akan menjadi penanggungjawab dan pemegang hak prerogratif.

2) Independensi

Independensi merupakan hubungan kemandirian, seperti hubungan antara 
Timur-Barat pada waktu berlangsungnya Perang Dingin, dimana pelaku dalam sistem tersebut nyaris tidak mempunyai interaksi dan pengaruh satu sama lain; dan merupakan hubungan antara dua sistem yang berbeda, yaitu sistem ekonomi pasar Barat dengan sistem ekonomi terpusat dan terencana Timur. Perbedaan sistem ekonomi yang dianut oleh tiap pihak memperkuat pilihan politik independensi, membangun kelembagaan ekonominya sendirisendiri. Pihak Timur tidak berpartisipasi dalam IMF, Bank Dunia, dan GATT. Akhirnya sistem Timur-barat ini runtuh, di akhir dekade 1980-an, seiring dengan pecahnya Blok Komunis Uni Soviet dan Eropa Timur.

3) Dependensi

Dependensi atau ketergantungan, terjadi dalam hubungan antara negara berkembang/miskin dengan negara maju/kaya, contohnya dalam sistem Utara-Selatan, yang diwarnai oleh ketimpangan antara Utara sebagai Dunia Pertama pihak tempat bergantung, dengan Selatan sebagai Dunia Ketiga, atau Dunia Keempat, sebagai pihak yang bergantung. Dependensi muncul jika ekonomi nasional sebuah negara (negara berkembang) mempunyai ketergantungan yang tinggi dengan, dan dipengaruhi oleh, pelaku atau peristiwa yang terjadi di negara lain (negara maju). Tetapi, sebaliknya, dalam hubungan ini pihak negara maju tidak mempunyai ketergantungan apapun dan tidak dipengaruhi oleh pelaku atau peristiwa di negara berkembang tersebut. Jadi dependensi adalah hubungan asimetrik.

Dalam artian politik, negara yang dependen tunduk kepada manajemen negara tempatnya bergantung. Hal ini sering dikeluhkan oleh negara berkembang sebagai tidak adii, karena struktur hubungan semacam ini mempunyai arti bahwa keputusankeputusan manajemen yang dibuat oleh negara maju merefleksikan minat, keinginan, dan tujuan pihaknya sendiri, bukan pihak negara berkembang. Dan ini menambah dimensi lain pada dependensi, yaitu perasaan di antara negara-negara berkembang Selatan bahwa mereka tidak saja tidak diajak ikut berbagi dalam sistem manajemennya, tetapi mereka juga tidak diajak berbagi sumber dan manfaat dari sistem dependensi ini, dan bahwa sistem tersebut ada untuk mempertahankan status dependensi negara berkembang kepada negara maju. Akibatnya, dependensi sering dilihat sebagai pelestarian ketergantungan dan keterbelakangan.

Dependensi yang cukup serius, terdapat dalam:

a. dependensi perdagangan. Pada umumnya, proporsi terbesar GNP negara berkembang bersumber dari perdagangan dengan negara maju, karena pasar domestiknya yang kecil. Dalam hal ini, negara berkembang menjadi amat sangat sensitif pada faktor-faktor di negara maju, seperti pasar dan politik yang membentuk permintaan negara maju. Lebih parah lagi jika proporsi terbesar dari ekspor negara berkembang terkonsentrasi dalam satu atau sedikit macam produk primer, atau terkonsentrasi pada satu atau sedikit pasar di negara maju, akan mempertajam kepekaan terhadap permintaan asing dan mempertinggi kepekaan dan kelemahan negara berkembang lemah terhadap fluktuasi permintaan yang terjadi di negara maju.

b. dependensi investasi. Prosentase terbesar dari penyedia kebutuhan investasi negara berkembang 
berada di tangan para investor negara maju. Akibatnya, negara maju mengawasi sektor-sektor produksi yang.paling penting dan strategis, seperti : bahan mentah, industri ekspor, sektor ekonomi yang relatif moderen dan dinamis, serta industri baru.

c. dependensi moneter. Dalam hal ini matauang dari negara berkembang langsung dikaitkan pada matakuang dari negara maju yang dominan, yang dengan demikian mengatur atau mempengaruhi secara nyata kebijakan moneter secara eksternal dan internal dari negara berkembang tersebut. Dependensi Moneter juga terjadi pada saat negara berkembang yang berada dalam kesulitan neraca pembayaran yang kronis, yang oleh karenanya menjadi tergantung pada bantuan eksternal dari IMF, dan dengan demikian IMF mempunyai hak untuk membentuk dan mempengaruhi kebijakan moneter domestik dan luar negeri dari negara berkembang tadi. Negara berkembang yang mencoba untuk menghindari pengaturan yang dikenakan oleh IMF, beralih kepada bank-bank komersial swasta untuk membiayai neraca pembayarannya, dengan resiko pembiayaan bunga yang lebih tinggi. Besarnya hutang Dunia Ketiga pada bank-bank swasta ini (sekitar 175 milyar US\$, 1979) merupakan indikasi dependensi moneter negara berkembang pada negara maju.

d. dependensi bantuan. Bantuan ekonomi yang diterima negara berkembang biasanya dikonsentrasikan pada satu sumber dari negara maju, yang menyebabkan terjadinya manipulasi dalam manajemen dan pembuatan keputusan oleh pihak donor. Lebih jauh lagi, bantuan bisa memperkuat dominasi perdagangan dan investasi negara maju di negara berkembang yang bersangkutan.

e. dependensi

teknologi.

Ketergantungan pasar menyebabkan negara berkembang harus memasok barang dan jasa kebutuhan negara maju yang pada umumnya berteknologi tinggi. Karena tidak memiliki teknologi tersebut, maka perolehan teknologi yang diperlukan tergantung pada pemberian oleh atau pembelian dari negara maju.

f. Di samping kelima macam dependensi di atas, ada juga dependensi ekonomi yang dilandasi oleh jenis hubungan bilateral khusus, seperti : keterikatan bekas jajahan (contoh : IGGI, persemakmuran), keterikatan politik secara informal, dan keterikatan militer.

\section{Hubungan Ekono-Politik Indonesia} dengan Dunia

Hubungan ekono-politik global perdagangan nasional Indonesia dikarakteristikkan oleh "pengakuan" terhadap "kepemimpinan" negara maju dan dependensi hampir di semua aspek ekonomi, baik dalam perdagangan, investasi, moneter, bantuan, maupun juga dependensi "bekas jajahan". Sebagai konsekuensinya, dampak negatif dari ekono-politik global juga melanda ekonopolitik Indonesia, antara lain terpaksa membiarkan kolusi dua perusahaan raksasa AS Caltex beroperasi di Indonesia, padahal Undang-undang Anti Trust AS sendiri melarang kolusi di dalam negeri AS, Counter trade antara tekstil indonesia dengan film AS, koreksi AS terhadap subsidi bunga ekspor Indonesia, berbagai jenis kuota impor yang menghadang ekspor Indonesia ke berbagai negara maju, 
ancaman-ancaman pencabutan GSP, pengiriman fact finding missions untuk menyelidiki keadaan perburuhan Indonesia, pengkaitan bantuan luar negeri kepada Indonesia dengan isyu three in one (human riight, green, dan NGO), dan masih banyak protes dan sanksi-sanki dari negara maju kepada Indonesia (misalnya kasus mobil nasional). Hal ini selain menunjukkan supremasi kekuasaan negara maju, atau sebaliknya, sikap tunduk sebuah negara berkembang, yang kesemuanya itu akibat tingkat ketergantungan yang parah, meskipun derajat ketergantungan tersebut semakin berkurang. situasi ekono-politik global ini pulalah yang melatarbelakangi persistennya kelemahan perdagangan lndonesia.

\section{Dependensi Dua Arah Suatu Tawaran Solusl}

Dari sudut pandang kepentingan Indonesia, sebetulnya istilah hubungan dependensi (dalam arti satu arah), negara maju memberi dan negara berkembang menerima) kurang tepat. Kenyataan perdagangan di atas menunjukkan bahwa meskipun Indonesia merasakan manfaat perdagangan, tetapi manfaat yang lebih besar masih dinikmati oleh negara maju. Ketergantungan negara maju pada Indonesia juga cukup besar, selain pada minyak dan sumberdaya alam dan manusia, dunia industri membutuhkan pula pasar ekspor Dunia Ketiga untuk menopang kemakmurannya. Menyadari persoalan dalam suatu interaksi ekono-politik adalah "pemburuan kekayaan" dan "supremasi kekuasaan", maka cara mengatasinya adalah dengan melakukan manajemen penyesuaian dalam bentuk manajemen konflik dan kerjasama yang diarahkan kepada semakin berkurangnya konflik dan semakin meningkatnya kerjasama. Upaya harus terus dilakukan untuk menggeser dari bentuk hubungan ekono-politik, dari hubungan dependensi (satu arah) menjadi "hubungan dependensi dua arah", atau saling membutuhkan. Untuk itu hendaknya selalu diupayakan agar sikap "kepeminpinan negara maju" semakin bergeser dari sikap "fatherhood" atau " unclehood" menjadi sikap "brotherhood" atau kemitraan sejajar.

\section{Penutup}

Pengaruh hubungan ekono-politik global terhadap perekonomian nasional Indonesia, khususnya terhadap sektor luar negerinya, sangat signifikan, baik yang bersifat positif maupun negatif. pengaruh yang negatif mengakibatkan kelemahankelemahan persisten sektor luar negeri Indonesia. Karakteristik dependensi dan kepemimpinan negara maju merupakan kenyataan tantangan yang harus dihadapi Indonesia.Cara mengatasi yang terbaik adalah dengan melakukan manajemen penyesuaian yang mengarah kepada terciptanya hubungan dependensi dua arah.

\section{Daftar Pustaka}

Adams, John, The Contemporary International Economy : A Reader, Znd. ed., St Martin's Press, New York, USA, 1985

Barnet, Richard J, \& Ronald E. Muller, Global Reach : The Power of The Multinational Corporations, Simon and Schuster New York, USA, 1974.

Endang sih Prapti, "Lingkungan Ekono-Politik Global Perdagangan Luar Negeri Indonesia", makalah yang disajikan dalam Seminar Internasional Strategi Pembangunan Ekonomi dan Bisnis di Indonesia "Refleksi dan Aktualisasi, dalam rangka Dies Natalis FE-UGM ke 40 tahun 1995.

Endang Sih Prapti, Peranan Jepang Dalam Sektor Luar Negeri Indonesia, Jurnal Fakultas Ekonomi Universitas Islam Indonesia, Desember 1996.

Hogendorn, Jan S. \& Wilson B. Brown, The New International Economy, Addison -Wesley Publishing Company, Reading Maddachussetts, USA, 1979. 
Kahler, Ruel \& Roland L. Kramer, International Marketing, 4 th. ed., South - Western Publishing Co., Ohio, USA, 1977

Muller, Roland E., Revitalizing America : Politics For Prospeity, Simon and Schuster, New York, 1980.
Staley, Charles E., International Economics : Analysis and Issues, Prentice - Hall, Inc., Englewood Cliffs, New Jersey 1970.

Spero, Joan Edelman, The Politics of International Economics Relations, Znd.ed., St. Martin Press, New York, USA, 1981 